\title{
MANAJEMEN TENAGA PENDIDIK DI MTS.S DARUL FALAH LANGGAPAYUNG KABUPATEN LABUHANBATU SELATAN
}

\author{
AZIDDIN HARAHAP \\ Dosen Tetap Sekolah Tinggi Ilmu Ekonomi Labuhanbatu
}

\begin{abstract}
ABSTRAK
Perencanaan tenaga pendidik Untuk merencanakan tenaga pendidik yang harus dilakukan atau dibuat yaitu mengidentifikasi atau menganalisis terlebih dahulu bentuk pekerjaan, tugas, dan jabatan yang sangat urgent dibutuhkan agar tidak terjadi kesalahan dalam recruitment dan penempatan posisi. Setelah merencanakan kebutuhan tenaga pendidik baik secara kuantitas dan kualitas barulah melakukan recruitment untuk mendapatkan calon-calon tenaga pendidik.
\end{abstract}

Pengawasan tenaga pendidik di Sekolah di MTS.s Darul Falah Langgapayung Pengawasan yang dilakukan untuk meningkatkan kinerja tenaga pendidik bukan semata-mata untuk mencari kesalahan ataupun kesenjangan dari pelakasanaan dari rencana yang ada pada diri guru didalam waktu belajar mengajar atau diluar kelas pada saat menyusun Rencana Program Pembelajaran (RPP), Silabus, serta instrumen pendukung lainnya yang digunakan dalam mendukung pembelajaran di kelas. Pengawasan yang dilakukan terhadap guru terutama pada tenaga pendidik yang melibatkan beberapa pihak, diantaranya Kepala Sekolah, Wakil Kepala Sekolah, dan Dinas Pendidikan. Mereka dilibatkan untuk membantu para tenaga pendidik dalam menyelesaikan permasalahan-permasalahan yang di alami oleh tenaga pendidik, baik didalam kelas maupun di luar kelas.

\section{A. Pendahuluan}

\section{Latar Belakang Masalah}

Tenaga pendidik dan kependidikan dalam proses pendidikan memegang peranan strategis terutama dalam upaya membentuk watak bangsa melalui pengembangan keperibadian dan nilai-nilai yang diinginkan. Dipandang dari dimensi pembelajaran, peranan pendidik (guru, dosen, pamong pelajar, instruktur, tutor, widyaswara) dalam masyarakat Indonesia tetap dominan sekalipun teknologi yang dapat dimanfaatkan dalam proses pembelajaran berkembang amat cepat. Hal ini disebabkan karena ada dimensi-dimensi proses pendidikan, atau lebih khusus lagi proses pembelajaran, yang diperankan oleh pendidik yang tidak dapat digantikan oleh teknologi. Fungsi mereka tidak akan bisa seluruhnya dihilangkan sebagai pendidik dan pengajar bagi peserta didiknya. ${ }^{1}$

Faktor guru apabila kita cermati merupakan faktor yang sangat penting dan tidak dapat diganti oleh apapun, karena guru sebagai subyek pendidik dan sebagai penentu keberhasilan dalam pendidikan itu sendiri. Nana Sudjana menyebutkan bahwa prestasi siswa sangat dipengaruhi oleh guru dan guru merupakan pelaku utama dalam peningkatan prestasi belajar siswa $^{2}$

Pendidikan sangat erat kaitannya dengan masa depan bangsa. Kemajuan yang dicapai suatu bangsa ditentukan oleh sistem pendidikan yang berfungsi dengan baik ${ }^{3}$ Berhasil atau tidaknya penyelenggaraan pendidikan bermutu sangat tergantung pada mutu para anggota

\footnotetext{
${ }^{1}$ Tim Dosen Administrasi Pendidikan UPI. Manajemen Pendidikan. Bandung: Alfabeta, (2009). h. 229.

${ }^{2}$ Haidir \& Salim. Strategi Pembelajaran. Medan: Perdana Publishing, (2014). h. 26.

${ }^{3}$ Syafaruddin. Manajemen Pendidikan Islam. Jakarta: Ciputat Press, (2005) h. 247
} 
masyarakat yang mengabdikan dan petugas yang melaksanakannya, mereka itu adalah tenaga pendidik. Melakukan peran dan fungsi sebagai kepala sekolah harus mampu memiliki strategi yang tepat untuk mengoptimalkan tenaga pendidik melalui kerja sama atau kooperatif, dan mendorong keterlibatan seluruh tenaga kependidikan dalam berbagai kegiatan yang menunjang program sekolah ${ }^{4}$.

Dalam hal ini kepala sekolah harusnya memiliki program perencanaan kegiatan yang dirumuskan secara operasional dengan memperhitungkan segala faktor yang berkaitan dengan pelaksanaan dan pencapaian program tersebut. ${ }^{5}$

Pengembangan perencanaan melibatkan semua aktivitas yang dirancang untuk meningkatkan kemampuan seseorang untuk melaksanakan seluruh tugasnya secara efektif, apapun perannya. ${ }^{6}$

Penyelenggaraan suatu sistem sekolah yang modern, melibatkan berbagai tenaga seperti administrator profesional, guru, tenaga pelayanan (Service Personnel), dan personil lainnya yang diperlukan untuk melaksanakan berbagai peran pada berbagai tempat dan tingkat organisasi. Kegiatan-kegiatan yang berkaitan dengan penataan staf (staffing) yang berkesinambungan dan tepat guna untuk mengisi posisi yang ada dengan personil yang memiliki keahlian, pengetahuan dan pengalaman yang didasarkan pada kualifikasinya ini disebut dengan perencanaan sumber daya manusia. yang mana proses perencanaan sumber daya manusia ini berkaitan dengan tiga kegiatan lainnya, yakni rekrutmen, seleksi, dan induksi. ${ }^{7}$

Dari observasi awal di MTS.s Darul Falah Langgapayung Kecamatan Sungai kanan, Kabupaten Labuhanbatu Selatan, sekolah yang memang basis pendidikan kepemerintahan adalah sekolah yang sudah baik dan dipersiapkan untuk cikal bakalnya peserta didik yang kompeten, mandiri dan juga cerdas. Sekolah ini merupakan gagasan dari masyarakat Sungai Kanan.

Permasalahan yang muncul pada tenaga pendidik di MTS.s Darul Falah Langgapayung Kecamatan Sungai kanan, Kabupaten Labuhanbatu Selatan ini adalah kurangnya tenaga pendidik menguasai kompetensi yang harus dimiliki oleh seorang pendidik, diantaranya seringnya lulusan seorang tenaga pendidik tidak sesuai dengan mata pelajaran yang diampunya, sehingga hal ini menyebabkan adanya masalah kualitas pendidik yang kurang baik, hak guru yang tidak diterima sesuai waktu yang ditentukan, kurangnya pengakuan dan penghargaan atas kinerja dari tenaga pendidik tersebut sehingga tenaga pendidik cenderung kurang afektif dalam melaksanakan tugasnya.

Sumber daya manusia di MTS.s Darul Falah Langgapayung Kecamatan Sungai kanan, Kabupaten Labuhanbatu Selatan memiliki dua status guru yaitu (GT),dan guru (GTT). Dan jumlah keseluruhan guru adalah termasuk ialah (30 orang) di MTS.s Darul Falah Langgapayung Kecamatan Sungai kanan, Kabupaten Labuhanbatu Selatan. Dalam suatu organisasi pendidikan merupakan penentu keberhasilan dan kegagalan pendidikan. Sebab walaupun sumber daya pendidikan lengkap, misalnya dana mencukupi, media lengkap, bahan

${ }^{4}$ Mastuhu. Menata Ulang Pemikiran Sistem Pendidikan Nasional, Yogyakarta: Safria Insani Press, (2003). h. 103-109.

${ }^{5}$ Rusydi Ananda dan Tien Rafida. Pengantar Evaluasi Program Pendidikan, Medan: Perdana Publishing, (2017). h. 5.

${ }^{6}$ Yusuf Hadijaya. Menyususn Strategi Berbuah Kinerja Pendidik Efektif, Medan: Perdana Publishing, (2013). h. 141.

${ }^{7}$ Amiruddin Siahaan dkk. Administrasi Satuan Pendidikan, Medan: Perdana Publishing, (2013). h. 94. 
pelajaran tersedia, sarana dan prasarana baik, serta lingkungan kerja memadai, tetapi pelaksanaan/sumber daya manusia sebagai tenaga pendidik, tidak berkompetensi dan tidak berdedikasi dengan baik, maka tujuan pendidikan yang telah dirumuskan akan sangat sedikit kemungkinan tercapai.

Lembaga pendidikan dapat meningkat manajemen tenaga pendidik dengan sistem manajemen peningkatan tenaga pendidikan yang berkualitas dibidang pendidikan. Kaitannya dengan permasalahan pendidikan dalam upaya meningkatkan manajemen tenaga pendidik tentunya tidak terlepas dari peran kepala sekolah, karyawan, tenaga pendidik dan elemen lainnya yang saling berkaitan dan berkesinambungan agar menjadi sebuah tim kerja sama untuk menciptakan bersama-sama dalam meningkatkan tenaga pendidik.

Fokus penelitian dalam penelitian ini adalah bagaimana Manajemen Tenaga Pendidik di MTS.s Darul Falah Langgapayung Kecamatan Sungai Kanan, Kabupaten Labuhanbatu Selatan. Berdasarkan uraian tersebut, maka permasalahan tentang manajemen tenaga pendidik yang seharusnya dilakukan oleh tenaga pendidik (guru) adalah menarik untuk diteliti dengan judul Manajemen Tenaga Pendidik di MTS.s Darul Falah Langgapayung.

\section{Rumusan Masalah}

1) Bagaimana perencanaan tenaga pendidik di MTS.s Darul Falah Langgapayung Kecamatan Sungai kanan, Kabupaten Labuhanbatu Selatan?

2) Bagaimana Pengorganisasian sumber daya tenaga pendidik di MTS.s Darul Falah Langgapayung Kecamatan Sungai kanan, Kabupaten Labuhanbatu Selatan

3) Bagaimana pengawasan atau evaluasi tenaga pendidik di MTS.s Darul Falah Langgapayung Kecamatan Sungai kanan, Kabupaten Labuhanbatu Selatan?

\section{Tujuan Penelitian}

1) Untuk mengetahui proses perencanaan tenaga pendidik di MTS.s Darul Falah Langgapayung Kecamatan Sungai kanan, Kabupaten Labuhanbatu Selatan ?

2) Untuk mengetahui proses pelaksanaan rencana tenaga pendidik di MTS.s Darul Falah Langgapayung Kecamatan Sungai kanan, Kabupaten Labuhanbatu Selatan ?

\section{Manfaat Penelitian}

1. Secara Teoritis.

a. Hasil penelitian diharapkan mampu menambah wawasan dan ilmu pengetahuan yang bermanfaat bagi peneliti sendiri dan menjadi acuan sebagai literature bagi peneliti selanjutnya.

b. Dapat menambah wawasan ilmu pengetahuan tentang manajemen tenaga pendidik dan diharapkan dapat dijadikan bahan lebih lanjut dalam pengembangan penelitian lain yang berkaitan dengan peningkatan manajemen tenaga pendidik yang berkualitas.

2. Secara Praktis

a. Hasil penelitian diharapkan dapat memberikan sumbangan pemikiran didalam pengembangan sumber daya manusia dalam manajemen tenaga pendidik.

\section{B. Metode Penelitian}

Penelitian ini menggunakan pendekatan kualitatif dengan jenis fenomenologi. Penelitian ini dilakukan di di MTS.s Darul Falah Langgapayung Kecamatan Sungai kanan, Kabupaten Labuhanbatu Selatan Sedangkan pelaksanaan penelitian ini mulai 05 Oktober sampai 13 Nov 2018. Dalam menentukan sumber data dilakukan dengan menggunakan metode purposive sampling. Sumber data dalam penelitian meliputi: Kepala Madrasah, Kepala TU, 
Guru, Kepala Labo-ratorium IPA, Kepala Laboratorium Komputer, dan Laboran Perpustakaan. Teknik pengumpulan data yang di-gunakan dalam metode kualitatif ini ada-lah wawancara dan analisis dokumen.

Wawancara yang dilakukan dalam penelitian ini adalah wawancara secara mendalam (indepth interview) yang bertujuan untuk menggali informasi terkait perencanaan, perekrutan, penempatan dan pengembangan pendidik dan tenaga kependidikan. Sedangkan analisis dokumen di-gunakan untuk memperoleh informasi yang bersifat tertulis (data sekunder) berkaitan sasaran program madrasah, strategi pengembangan pendidik dan tenaga kependidikan, dan kegiatan program pengembangan pendidik dan tenaga kependidikan di MTS.s Darul Falah Langgapayung Kecamatan Sungai kanan, Kabupaten Labuhanbatu Selatan.

Dalam penelitian kualitatif manusia atau peneliti sendiri yang menjadi instrumen penelitian yang utama. Instrumen yang digunakan dalam penelitian ini adalah peneliti itu sendiri yaitu pada saat permasalahan belum jelas dan pasti, maka yang menjadi instrumen adalah peneliti sendiri. Tetapi setelah masalah yang telah dipelajari jelas, maka dikembangkan suatu instrumen. Instrumen yang dikembangkan adalah pedoman wawancara. Pedoman wawancara yang dibuat adalah pedoman wawancara mendalam (indepth interview) untuk memperkuat dokumentasi.

Keabsahan data yang dilakukan dalam penelitian ini menggunakan kredi-bilitas, dependabilitas dan konfirmabilitas ${ }^{8}$ Kredibilitas (credi-bility) adalah seberapa besar data yang didapatkan dapat dipercaya dan diterima kebenarannya, yaitu dengan cara meningkatkan ketekunan dan menggunakan triangulasi sumber dan teknik. Triangulasi disini yaitu melakukan cross check antar responden (triangulasi sumber) dan cross check antar teknik pengumpulan data (tri-angulasi teknik) untuk mendapatkan data yang valid dan kredibel. Dependabilitas (Dependability) adalah konsisten, yaitu memberikan hasil yang konsisten atau kesamaan hasil sehingga dapat dipercaya. Penelitian ini menggunakan instrument pengumpulan data berdasarkan konsep-konsep yang digunakan dan dikonsultasikan dengan pembimbing. Dan konfirmabilitas (Komfirmability) adalah pembuktian kebenaran yang dilakukan untuk menguji hasil penelitian yang dilakukan dengan cara membicarakan hasil penelitian dengan responden untuk memastikan data atau informasi yang akan ditulis dalam laporan penelitian sudah sesuai dengan kenyataan.

Teknik analisis data untuk masing-masing lokasi penelitian yang digunakan dalam peneltian ini mengadopsi dari teknik analisis data yang diungkapkan oleh Miles \& Huberman ${ }^{9}$ Teknik analisis data dilakukan secara interaktif dan berlangsung secara terus menerus sampai tuntas, sehingga datanya sudah jenuh. Kegiatan analisis data pada penelitian ini yaitu dimulai dari pengumpulan data, reduksi data, display data, dan kesimpulan/verifikasi.

\section{Temuan dan Pembahasan Hasil Penelitian}

Berdasarkan hasil penelitian Manajemen tenaga pendidik di MTS.s Darul Falah Langgapayung sudah berjalan dengan baik, jika dilihat dari kerja sama tim yang bertanggung jawab yang dimiliki oleh kepala sekolah, staf, guru, siswa dan orang-orang yang terlibat didalam meningkatkan kualitas pendidikan telah dilakukan secara baik, jelas dan terarah.

Adapun penjabaran dalam pembahasan ini yang berpedoman pada pertanyaan penelitian tentang:

\footnotetext{
${ }^{8}$ Nasution, S. Metode penelitian naturalistik-kualitatif. Bandung: Tarsino. 2003). h. 114

${ }^{9}$ Sugiyono. Metode penelitian manajemen. Bandung: Alfabeta. (2014). h. 404
} 


\section{Perencanaan Tenaga Pendidik}

Dari hasil wawancara yang telah dilakukan oleh peneliti dengan kepala sekolah di MTS.s Darul Falah Langgapayung, perencanaan yang dibuat disekolah tersebut melalui proses tahapan seperti mengidentifikasi atau menganalisis terlebih dahulu bentuk pekerjaan, tugas, dan jabatan yang sangat urgent dibutuhkan agar tidak terjadi kesalahan yang kemudian melakukan perekrutan sebagaimana juga penyeleksian untuk mendapatkan calon tenaga pendidik yang sesuai dengan tamatan/lulusan jurusan bidang studi yang dibutuhkan.

Dalam ilmu manajemen juga dijelaskan bahwa salah satu fungsi pokok manajemen adalah perencanaan, dimana dalam ilmu manajemen menjelaskan bahwa fungsi pokok manajemen terdiri dari perencanaan, koordinasi, pelaksanaan, pengawasan dan evaluasi. Perencanaan merupakan salah satu fungsi pokok manajemen yang pertama yang harus dijalankan. Sebab tahap awal dalam melakukan aktivitas perencanaan tenaga pendidik sehubungan dengan pencapaian tujuan sekolah adalah dengan membuat perencanaan.

Peraturan Menteri Pendidikan Republik Indonesia Nomor 20 Tahun 2003 pada pasal 39 ayat 2 yang berbunyi "Pendidik merupakan tenaga profesional yang bertugas merencanakan dan melaksanakan proses pembelajaran, melakukan pembimbingan dan pelatihan, serta melakukan penelitian dan pengabdian kepada masyarakat, terutama bagi pendidik pada perguruan tinggi"”.

Secara umum perencanaan merupakan proses penentuan tujuan tenaga pendidik dan kemudian menyajikan (mengartikulasikan) dengan jelas strategi-strategi (program), taktiktaktik (tata cara melaksanakan program tenaga pendidik), serta tindakan yang diperlukan untuk mencapai tujuan pendidikan secara menyeluruh.

\section{Pengorganisasian Tenaga pendidik}

Pengorganisasian merupakan langkah kedua yang perlu dilaksanakan oleh seorang kepala madrasah dan unsur pimpinan lainnya memanej madrasah yang dipimpinnya. Kegiatan mengorganisasikan adalah tindakan membangun kerjasama antar sumber daya yang dimiliki oleh sekolah/madrasah. Dikarenakan tema penelitian ini menyangkut peningkatan kinerja guru, maka kegiatan pengorganisasiannya adalah SDM guru sebagai subyek kegiatan pengorganisasian kepala madrasah.

Kepala MTS.s Darul Falah dan unsur pimpinan lainnya yaitu PKM I bidang kurikulum, PKM II bidang Kesiswaan dan Humas dan PKM III bidang Sarana/Prasarana mengimplementasikan kegiatan pengorganisasian ini dengan mendelegasikan tugas pokok dan fungsi (Tupoksi) guru beserta tambahan jabatan bagi guru lainnya. berikut:

Jabatan guru dan tambahan jabatannya pada MTS.s Darul Falah dapat diidentifikasi sebagai

1. Kepala Madrasah,

2. Pembantu Kepala Madrasah (PKM I) bidang kurikulum,

3. Pembantu Kepala Madrasah (PKM II) bidang kesiswaan dan humas,

4. Pembantu Kepala Madrasah (PKM III) bidang sarana/prasarana,

5. Wali kelas,

6. Kepala laboratorium IPA,

7. Kepala perpustakaan,

8. Kepala praktek komputer, 
9. Operator ruang multimedia,

10. Guru Bimbingan dan Penyuluhan (BP),

11. Guru piket,

12. Guru mata pelajaran. ${ }^{10}$

Berdasarkan studi dokumentasi pada MTS.s Darul Falah pada tanggal 12 nov ember 2018 di MTS.s Darul Falah.

\section{Pengawasan Tenaga pendidik}

Dari hasil wawancara yang telah dilakukan oleh peneliti dengan kepala sekolah di MTS.s Darul Falah Langgapayung, pengawasan yang dilakukan adalah kepala sekolah adalah pengawas yang tidak ada henti-hentinya mengawasi kinerja tenaga pendidik agar tercapainya visi dan misi sekolah. Wakil kepala sekolah juga ikut berperan aktif dalam mengelola sumber daya manusia atau tenaga di dalam menjalankan peran dan fungsinya sebagai tenaga pendidik di dalam sekolah. Pengevaluasian hasil belajar siswa (raport) yang mana itu menjadi alat ukur keberhasilan dari seorang tenaga pendidik, serta profesionalisme seorang guru di dalam menjalankan fungsi tugas serta tanggung jawabnya menjadi seorang tenaga pendidik.

Pengawasan yaitu usaha sistematik menetapkan standar pelaksanaan dengan tujuan perencanaan, merancang sistem informasi umpan balik, membandingkan kegiatan nyata dengan standar yang dibuat, mengukur dan menentukan daviasi-daviasi dan mengambil tindakan koreksi yang menjamin bahwa semua guru yang dimiliki telah dipergunakan dengan efektif dan efisien

Pengawasan dilakukan untuk memastikan apakah guru atau jabatan-jabatan lain dapat melaksanakan tugas dan tanggungjawabnya dengan baik sesuai dengan rencana atau tidak. Kepala MTS.s Darul Falah melalui PKM I bidang kurikulum berperan dalam melaksanakan pengawasan ini. Dimulai dari tugas guru, wali kelas, guru BP, kepala perpustakaan, laboratorium IPA, kepala ruang praktek komputer dan guru piket. Guru piket juga berperan dalam melakukan kegiatan pengawasan hanya terhadap guru pada saat ia bertugas. Maksudnya adalah bahwa kelancaran pelaksanaan proses pembelajaran setiap harinya secara umum diawasi oleh guru piket yang berbeda karena guru piket bertugas secara bergantian. ${ }^{11}$

Bagi guru yang tidak mentaati peraturan dan tata tertib madrasah seperti terlambat hadir ke madrasah dan masuk kelas, absen mengajar tanpa keterangan, kepala madrasah memanggil ke ruangannya berdasarkan informasi dari guru piket secara tertulis di buku piket harian guru untuk menerima peringatan/teguran. Hal ini dilakukan untuk melaksanakan fungsinya sebagai supervisor sekaligus juga untuk menghargai/respek terhadap tugas piket. Tindakan kepala ini sebagai bentuk punishment (sanksi/hukuman). Prosedur pemberian sanksi ini pertama-tama adalah peringatan secara lisan sampai 3 kali. Peringatan secara tertulis dilakukan setelah itu. Meskipun namanya peringatan tetapi intinya adalah bimbingan dan motivasi bersifat komunikatif dan persuasif. Bentuknya adalah bimbingan dan motivasi terhadap pelanggaran disiplin. Tujuannya adalah agar guru dapat melaksanakan tugas dan tanggungjawabnya sebagai guru dengan baik. Peringatan tersebut kemudian dicatat sebagai peringatan I (pertama). Yang jelas menurutnya, setiap seminggu sekali kepala madrasah memberikan bimbingan dan motivasi kepada guru-gurunya. Bagi guru yang menunjukkan kinerja yang tinggi diberikan reward (penghargaan/hadiah) berupa pujian dan promosi. ${ }^{12}$ Tindakan yang dilakukan oleh kepala demikian terutama ditujukan terhadap guru berstatus PNS (Pegawai Negeri Sipil), dan jika yang tidak menaati peraturan dan melalaikan tugas itu adalah guru honorer (guru pengabdi), maka

${ }^{10}$ Zulmahdi Siregar S.Pdi. Kepala MTS.s Darul Falah, Wawancara di MTS.s Darul Falah, pada tanggal 13 November 2018.

${ }^{11}$ Zulmahdi Siregar S.Pdi, Kepala MTS.s Darul Falah, Wawancara di MTS.s Darul Falah, tanggal 12 November 2018.

${ }^{12}$ Ibid. 
kepala mengkomunikasikan permasalahan tersebut dengan komite madrasah mengenai solusi yang perlu dilakukan. ${ }^{13}$

Pengawasan terhadap jalannya proses pembelajaran apakah guru telah melaksanakan tugas pembelajaran dengan baik atau belum terhadap siswa, kepala madrasah bersama pengawas fungsional Departemen Agama kabupaten Labuhanbatu selatan melakukan supervisi kelas. Menurut penuturannya, ia telah melakukan kegiatan supervisi kelas terhadap 3 (tiga) orang guru, yaitu guru Alquran Hadis, Sejarah Kebudayaan Islam dan Sejarah Umum. Adapun pengawas fungsional Departemen agama (Amin Maskur MA) telah melakukan supervisi kelas sebanyak 2 (dua) kali, yaitu pelajaran bahasa arab dan fiqih. Setelah dilakukan supervisi di kelas kemudian guru tersebut diajak berdiskusi sebagai bentuk bimbingan untuk tindak lanjut. ${ }^{14}$

\section{Penutup \\ 1. Kesimpulan}

Perencanaan tenaga pendidik Untuk merencanakan tenaga pendidik yang harus dilakukan atau dibuat yaitu mengidentifikasi atau menganalisis terlebih dahulu bentuk pekerjaan, tugas, dan jabatan yang sangat urgent dibutuhkan agar tidak terjadi kesalahan dalam recruitment dan penempatan posisi. Setelah merencanakan kebutuhan tenaga pendidik baik secara kuantitas dan kualitas barulah melakukan recruitment untuk mendapatkan calon-calon tenaga pendidik.

Kepala Sekolah mengatakan bahwa pelaksanaan rencana tenaga pendidik dilaksanakan sesuai perencanaan yang telah disusun pada rapat kerja, baik itu yang bersifat rutin maupun insidental. Dilakukannya orientasi yang mana orientasi merupakan cara pengarahan dengan memberikan informasi yang perlu supaya kegiatan dapat dilakukan dengan baik. Orientasi ini diberikan kepada pegawai baru dengan tujuan untuk mengadakan pengenalan dan memberikan solusi atas berbagai masalah yang dihadapinya.

Pengawasan tenaga pendidik di Sekolah di MTS.s Darul Falah Langgapayung Pengawasan yang dilakukan untuk meningkatkan kinerja tenaga pendidik bukan semata-mata untuk mencari kesalahan ataupun kesenjangan dari pelakasanaan dari rencana yang ada pada diri guru didalam waktu belajar mengajar atau diluar kelas pada saat menyusun Rencana Program Pembelajaran (RPP), Silabus, serta instrumen pendukung lainnya yang digunakan dalam mendukung pembelajaran di kelas. Pengawasan yang dilakukan terhadap guru terutama pada tenaga pendidik yang melibatkan beberapa pihak, diantaranya Kepala Sekolah, Wakil Kepala Sekolah, dan Dinas Pendidikan. Mereka dilibatkan untuk membantu para tenaga pendidik dalam menyelesaikan permasalahan-permasalahan yang di alami oleh tenaga pendidik, baik didalam kelas maupun di luar kelas.

\section{Daftar Pustaka}

Ananda, Rusydi, \& Rafida, Tien. (2017). Pengantar Evaluasi Program Pendidikan, Medan: Perdana Publishing.

\footnotetext{
${ }^{13}$ Ibid.; Pangaribuan Siregar, Ketua Komite MTS.s Darul Falah, Wawancara di MTS.s Darul Falah, tanggal 18 November 2018.

${ }^{14}$ Zulmahdi Siregar S.Pdi,, Kepala MTS.s Darul Falah, Wawancara di MTS.s Darul Falah, tanggal 12 ovember t 2018.
} 
Hadijaya, Yusuf. (2013). Menyusun Strategi Berbuah Kinerja Pendidik Efektif, $\quad$ Medan: Perdana Publishing.

Haidir \& Salim, (2014). Strategi Pembelajaran. Medan: Perdana Publishing.

Mastuhu, (2003). Menata Ulang Pemikiran Sistem Pendidikan Nasional, Yogyakarta: Safria Insani Press.

Nasution, S. (2003). Metode penelitian naturalistik-kualitatif. Bandung: Tarsino.

Siahaan, Amiruddin dkk, (2013). Administrasi Satuan Pendidikn, Medan: Perdana Publishing.

Syafaruddin, (2005), Manajemen Pendidikan Lembaga Islam, Jakarta: Ciputat Press.

Sugiyono. (2014). Metode penelitian manajemen. Bandung: Alfabeta.

Tim Dosen Administrasi Pendidikan Universitas Pendidikan Indonesia. (2012). Manajemen pendidikan. Bandung: Alfabeta. 